\title{
Gabo em seu labirinto
}

Tatiana de Aquino Mascarenhas ${ }^{1}$

VIEIRA, F. P. G. Gabo, cronista da América: história, memória e literatura. São Paulo: Intermeios; Campinas: Unicamp, 2020.

Resenha recebida em: 21/04/2021

Resenha aprovada para publicação em: 30/04/2021

Na noite em que recebeu o prêmio Nobel de Literatura, Gabriel García Márquez quebrou os protocolos ao comparecer à cerimônia vestido com um típico liquiliqui. A dessemelhança no traje, no entanto, representava apenas uma parte da oposição simbólica que ele traçaria na ocasião, por meio de seu discurso. Nele, o escritor destacou a existência de um nós - os latino-americanos, dos quais se colocava como porta-voz - e de um outro, os europeus para quem falava. Na relação que estabelecia entre esses dois mundos, a América Latina aparecia como vítima do saqueio, da violência e das tentativas de interpretação com base em esquemas alheios, das quais resultaria sua persistente solidão.

Essas palavras ecoavam, além de um protesto, uma visão que vinha ganhando força desde os anos 1950, fomentada por uma geração de escritores, para os quais a América Latina deveria ser compreendida como uma unidade com um passado, um presente e um destino comuns. À altura da cerimônia de outorga do Nobel, o continente havia passado, no intervalo de poucas décadas, por mais de uma revolução e assistido a uma sucessão de golpes de Estado. Os olhos da Europa observavam atentos essas convulsões e, diante deles, García Márquez se colocava como intérprete e tradutor dos impasses e sonhos latino-americanos.

Como isso foi possível? De que modo o jornalista de um pequeno povoado na Colômbia havia se tornado a voz autorizada a falar sobre a América Latina, mesmo nunca

\footnotetext{
${ }^{1}$ Bacharel e Mestre em Psicologia pelo IP-USP; Bacharel em História pela FFLCH-USP. Em 2020, concluiu a pesquisa Um rabo de burro para Pinochet: a resistência à ditadura chilena na obra A aventura de Miguel Littín clandestino no Chile, de Gabriel García Márquez. E-mail: amtatian@gmail.com
} 
tendo sido um pensador estritamente político ou se dedicado à produção ensaística que fervilhou no continente ao longo do século XX? Compreender como esse processo se deu foi um dos objetivos que mobilizou Felipe de Paula Góis Vieira em sua pesquisa de doutorado realizada no Programa de Pós-graduação em História da Universidade Estadual de Campinas (Unicamp) e publicada em 2020, no livro Gabo, cronista da América: história, memória e literatura. A publicação é fruto de um percurso investigativo iniciado há mais de dez anos, com uma pesquisa sobre a obra Doze contos peregrinos, e aprofundado na dissertação de mestrado (2012), De Macondo a McOndo: os limites do Real Maravilhoso como discurso de representação da América Latina (1947-1996).

Já em Gabo, cronista da América: história, memória e literatura, Vieira busca compreender como Gabriel García Márquez narrou a si mesmo, ficcionalizando a própria vida e a entrelaçando à história do continente. O título do livro, que traz o apelido pelo qual o escritor era conhecido entre os amigos, dá a ideia de uma intimidade construída também entre pesquisador e seu objeto de estudo. Vieira interroga, vasculha, desconfia e habilmente se desvencilha das narrativas sedutoras de Gabo. O resultado entregue a nós, leitores, é uma análise sofisticada, que, se por um lado contribui para desmistificar a figura do artista colombiano, por outro, torna-o ainda mais fascinante.

$\mathrm{Na}$ introdução, Vieira apresenta algumas importantes considerações sobre as relações entre História e Literatura, suas aproximações e distanciamentos, recuperando autores que contribuíram para a construção desse território de fronteira. Tendo em vista a pluralidade desse diálogo, o historiador esclarece seu ponto de partida: a compreensão de que os textos não são estáticos, mas sim dotados de significados que dependem dos questionamentos e do olhar dos leitores. Dentro dessa perspectiva, a literatura não seria um reflexo da sociedade que se pretende representar, mas sim mais uma tentativa de construção de significados e, consequentemente, daquilo que chamamos de realidade.

Esse entendimento de que os significados não estão contidos no referente, mas se constroem no processo de narração, é fundamental para compreendermos a hipótese de Vieira, trabalhada já no primeiro capítulo do livro, A invenção de um autor: a trajetória e as histórias por trás da vida de Gabriel García Márquez, no qual são apresentados argumentos para mostrar que "em mais de um sentido, Gabo se fez" (p. 52). Segundo o 
pesquisador, por meio das histórias que difundiu sobre si mesmo ao longo da vida, García Márquez não apenas firmou seu lugar como mediador sobre os assuntos latinoamericanos, como também construiu um verdadeiro projeto de memória, frequentemente reproduzido por seus biógrafos e admiradores.

De acordo com Vieira, a partir das pistas que deixou em entrevistas, crônicas e discursos, Gabo consolidou a ideia de um mito de origem, segundo o qual os anos de sua infância na pequena Aracataca, a convivência com o olhar encantado de sua avó e com as narrativas sobre o passado colombiano transmitidas pelo avô teriam deixado nele a inspiração literária que encontraria seu auge, décadas depois, na obra Cem Anos de Solidão. Com o tempo, a cidade da infância e a Macondo de seus livros passariam a ser comparadas e, não raro, identificadas.

Além do mito de uma infância prodigiosa, que cumpriria o papel de legitimá-lo como escritor, outros mitos contribuíram para uma determinada figura pública assumida por Gabo. De acordo com Vieira, o escritor deliberadamente edificou sua importância em meio aos acontecimentos de seu tempo, ao entrelaçar seu passado familiar e sua vida a importantes eventos do continente. A Guerra dos Mil Dias, o massacre dos trabalhadores de Ciénaga e a Revolução Cubana são apenas alguns dos episódios que aparecem mesclados em sua vida e à de seus antepassados. Desse modo, segundo o pesquisador, García Márquez colocou-se como testemunha da História, semeando um passado que muitas vezes disputou espaço com as explicações de historiadores e sociólogos.

No segundo capítulo do livro, A construção do homem público: Gabriel García Márquez e a sedução do poder, Vieira discute o gradual processo de engajamento do escritor com os assuntos do continente e de que forma, a partir dos anos 1970, ele despontou internacionalmente como mediador político. Para o pesquisador, esse lugar foi pacientemente construído a partir de escolhas estratégicas do escritor, que diante das polêmicas envolvendo a intelligentsia de seu tempo - sendo o Caso Padilla a mais emblemática - soube se colocar frente a interesses divergentes. Com isso, conquistou a confiança e amizade de homens poderosos, como Fidel Castro, ao mesmo tempo que se colocou como defensor dos oprimidos que habitavam o continente; em sua visão, um lugar marcado pelo trauma e pelas promessas não cumpridas. 
Essa América Latina das utopias negadas encontraria lugar, em 1967, no maior sucesso de García Márquez, abordado por Vieira no capítulo Cien años de soledad: uma reflexão sobre a história, a memória e o esquecimento. Apesar de as principais vertentes de interpretação da crítica literária obscurecerem o aspecto trágico da obra ao focarem no tema da violência ou no rótulo "realismo mágico", é sobre esse destino de sofrimento que o pesquisador realiza sua análise. A leitura da tragédia vivida pelos habitantes de Macondo e repetida a cada geração é pensada em suas relações com a História, a memória e os sucessivos pactos de esquecimento vividos pelas personagens. Apenas a memória, entendida aqui como ato de resistência, e uma História feita às margens dos discursos oficiais seriam capazes de redimir o povoado e seus habitantes. E essa tarefa, constata Vieira, é entregue ao leitor, que deve lembrar e impedir que outros Macondos se repitam.

As críticas à História se estendem no quarto e último capítulo do livro, $O$ século XIX e o contexto das independências políticas na literatura de Gabriel García Márquez. Por meio da análise de duas obras do escritor colombiano, $O$ outono do patriarca e $O$ general em seu labirinto, Vieira discute como Gabo perseguiu o passado, não apenas para alcançar nossos "males de origem", mas também como pretexto para denunciar a conjuntura latino-americana da segunda metade do século XX. Se o patriarca encarna a figura dos ditadores e suas arbitrariedades, o Bolívar garciamarqueano é um lembrete de um processo inconcluso e um chamado a uma América unificada, autônoma, que rompa finalmente com a peste do esquecimento.

Ao afirmar que "a vida não é a que a gente viveu, e sim a que a gente recorda, e como recorda para contá-la"2, García Márquez sinalizou o aspecto de construção narrativa inerente às autobiografias. De um lado, está em jogo nossa memória - lacunar, porosa e, assim, entregue à ficcionalização -, de outro, as escolhas mais ou menos conscientes que fazemos ao narrar nossa trajetória. Por isso, lembra Vieira, há sempre algo de teatralização em nossa existência e, no caso de García Márquez, essa performance se deu tanto em suas ficções quanto em sua vida pública, processo que o legitimou como observador privilegiado e voz autorizada a falar das questões latino-americanas.

\footnotetext{
${ }^{2}$ Epígrafe do livro Viver para contar (GARCÍA MÁRQUEZ, G. Viver para contar. Rio de Janeiro: Record, 2014).
} 
No fim, as pistas que o pesquisador decifra ao percorrer os muitos labirintos construídos por Gabo fazem com que o livro, mesmo ao virar da última página, continue a suscitar reflexões e uma saudável desconfiança frente a essa figura fugidia e complexa que esse artista representou. Depois de Gabo, cronista da América, qualquer novo texto do escritor colombiano que nos caia nas mãos será necessariamente atravessado pela leitura de Felipe Vieira. E nisso reside um dos grandes méritos de uma pesquisa: a capacidade de nos impregnar e de nos reposicionar. 